\title{
Maturity Evaluation of National Agro-technology Park Innovation Network Based on Improved Matter-element Extension Model From the Perspective of Intensive Development
}

\author{
Huimin Duan ${ }^{1}$, Ming $\mathrm{Huo}^{2,}{ }^{*}$, Xiaoyu Zhang ${ }^{1}$, and Liang Zhang ${ }^{3}$ \\ ${ }^{1}$ College of Economics and Management, Shandong Agricultural University, China \\ ${ }^{2}$ National Innovation capability Evaluation Center of Agricultural Science and Technology Park \\ ${ }^{3}$ College of Information Science and Engineering, Shandong Agricultural University, China
}

\begin{abstract}
Based on the improved match-element extension model, the maturity of collaborative innovation network in China's agricultural science and technology parks was explored with 257 national agricultural science and technology parks as research objects. The results show that: (1) the results obtained by measuring the maturity level of collaborative innovation network in national agricultural science and technology parks by asymmetric proximity degree are more consistent with the actual situation;(2) the maturity of collaborative innovation networks in national agricultural science and technology parks are good. Therefore, the park should replace the traditional resource input-driven development model through innovation-driven development to achieve low energy consumption, intensive and high-quality development.
\end{abstract}

\section{Introduction}

China's National Agricultural Science and Technology Parks are becoming a model for the current innovation of agricultural science and technology, the application of agricultural technology and the development of agricultural industry, and an important pole of growth in realizing the optimal allocation of agricultural and rural resources, building an innovative country and a green new countryside, and promoting agricultural modernization ${ }^{[1]}$. After decades of changes, along with the development of agricultural science and technology in China, agricultural science and technology parks at all levels are being built in full swing in order to activate the new engine of rural revitalization and cultivate agricultural high-tech industry [2]. However, at the present stage, the low energy consumption integrated innovation platform of in China's agricultural science and technology parks has not yet been formed, and the input of innovation resources has not been brought into full play. Therefore, the driving effect of the core competitiveness of collaborative innovation ability on the parks has not been significantly exerted.

The innovation theory was first put forward clearly in Schumpeter's Theory of Economic Development, which mainly studies the role of technological innovation in the process of economic development. Subsequently, Professor Cooke proposed the concept of regional innovation and drew the conclusion that all walks of life converged to form a complete regional innovation system. The research of innovation theory in China is later than that abroad. Kejie $\mathrm{Li}^{[3]}$ studied the regional innovation network of industrial clusters and discussed how to promote the cooperation among internal actors to promote collaborative innovation, so as to improve the innovation ability of the whole industrial cluster. Then, Wenhua Zhai ${ }^{[4]}$ discussed agricultural science and technology ecology park (ASTEP), and based on its own system, subsystem and the interaction of various levels of factors and environment, hoped to find ways to improve the ASTEP effect and promote the cooperation and interaction of innovation subjects such as industry, university, research institute, farmers, and government. Finally parks achieve the optimal situation of agricultural ecological benefits and economic benefits.

At present, most researches on agricultural science and technology parks take a specific park example as the carrier to study the innovation ability of the park. Taking Tianjin Binhai High-tech Zone as an example, Zongyu $\mathrm{Hu}^{[5]}$ studied the innovation synergy relationship among various innovation subjects in the park and its impact on the park from the perspective of innovation community. Hanwen $\mathrm{Liu}^{[6]}$ proposed some related theories on the basis of collaborative innovation in science and technology parks, such as growth pole theory, industrial cluster theory, seedbed theory and triple helix theory. Lin Sen et al. ${ }^{[7]}$ conducted a study on universities and science and technology parks, and found that the collaborative innovation network between the parks remains to be developed, with insufficient innovation ability and relatively low field application rate of scientific and technological achievements.

Through the above literature review, it can be seen that the existing literature lacks an evaluation method for the aggregation capacity of collaborative innovation network of agricultural science and technology parks,

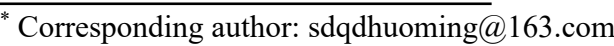


and how to define the influencing factors that affect the aggregation capacity of collaborative innovation network. Based on this, this paper introduced the concept of maturity into the science and technology innovation network inside the park, combined with the improved matter element extension model to explore the quality of collaborative innovation network of agricultural science and technology parks in China. Furthermore, some suggestions are provided for the improvement of collaborative innovation ability and innovation development of National Agro-technology Parks.

\section{Index system}

Considering the purpose of evaluating the maturity of network innovation in National Agro-technology Parks, combined with qualitative and quantitative methods, the evaluation system of this paper is shown in Table 1.

Table 1. Evaluation Index system of Collaborative Innovation Network maturity.

\begin{tabular}{|c|c|}
\hline First-level index & Second-level index \\
\hline \multirow{5}{*}{ Network scale(A1) } & Number of enterprises / core area(C1) \\
\hline & Number of R \& D institutions / core area(C2) \\
\hline & Number of Innovation and Entrepreneurship Service institutions / Core area(C3) \\
\hline & Number of investment and financing institutions / core area(C4) \\
\hline & Number of employees / core area(C5) \\
\hline \multirow{5}{*}{$\begin{array}{l}\text { Network self-updating } \\
\qquad(\mathrm{A} 2)\end{array}$} & $\begin{array}{l}\text { Changes of the number of enterprises in the current period / number of enterprises in the base } \\
\text { period(C6) }\end{array}$ \\
\hline & $\begin{array}{l}\text { Changes in the number of current R \& D institutions in the current period / number of R \& D } \\
\text { institutions in the base period(C7) }\end{array}$ \\
\hline & $\begin{array}{l}\text { Changes in the number of innovative and entrepreneurial service institutions in the current period / } \\
\text { number of innovative and entrepreneurial service institutions in the base period(C8) }\end{array}$ \\
\hline & $\begin{array}{l}\text { Changes in the number of investment and financing institutions in the current period / number of } \\
\text { investment and financing institutions in the base period(C9) }\end{array}$ \\
\hline & $\begin{array}{l}\text { Changes in the number of employees in the current period / number of employees in the base } \\
\text { period(C10) }\end{array}$ \\
\hline \multirow{5}{*}{$\begin{array}{l}\text { Network openness } \\
\text { (A3) }\end{array}$} & Number of projects introduced into the park(C11) \\
\hline & $\begin{array}{l}\text { Number of "new varieties, new technologies, new products and new facilities" introduced into the } \\
\text { park(C12) }\end{array}$ \\
\hline & Number of transformation achievements of the park(C13) \\
\hline & Amount of funds for international cooperation(C14) \\
\hline & Total foreign exchange earnings from exports of the park(C15) \\
\hline \multirow{3}{*}{$\begin{array}{l}\text { Network stability } \\
\quad \text { (A4) }\end{array}$} & $1 /$ change in the number of cooperative units in the current period(C16) \\
\hline & $\begin{array}{l}1 / \text { changes in the number of industry-university-research cooperation projects in the current } \\
\text { period(C17) }\end{array}$ \\
\hline & Current management committee staff / base period management committee staff(C18) \\
\hline \multirow{3}{*}{$\begin{array}{l}\text { Network dispersion } \\
\quad \text { (A5) }\end{array}$} & R\&D funds / (number of enterprises + number of R \& D institutions) (C19) \\
\hline & R\&D Personnel/(number of enterprises + number of R \& D institutions) (C20) \\
\hline & $\begin{array}{l}\text { Original value of large-scale scientific research equipment / (number of enterprises + number of } \mathrm{R} \\
\& \mathrm{D} \text { institutions) (C21) }\end{array}$ \\
\hline \multirow{4}{*}{$\begin{array}{l}\text { Diversity of network } \\
\text { connections(A6) }\end{array}$} & $\begin{array}{l}\text { Number of scientific research institutions / (number of enterprises + number of investment } \\
\text { institutions + number of scientific research institutions + number of innovative and } \\
\text { entrepreneurial institutions) (C22) }\end{array}$ \\
\hline & $\begin{array}{l}\text { Number of science and technology incubators/(number of enterprises + number of investment } \\
\text { institutions + number of scientific research institutions + number of innovative and } \\
\text { entrepreneurial institutions) (C23) }\end{array}$ \\
\hline & $\begin{array}{l}\text { Number of technology trading institutions / (number of enterprises }+ \text { investment institutions }+ \\
\text { number of scientific research institutions }+ \text { number of innovative and entrepreneurial institutions) } \\
\text { (C24) }\end{array}$ \\
\hline & $\begin{array}{l}\text { Number of investment institutions / (number of enterprises }+ \text { investment institutions }+ \text { number of } \\
\text { scientific research institutions }+ \text { number of innovative and entrepreneurial institutions) }(\mathrm{C} 25)\end{array}$ \\
\hline
\end{tabular}

The design of the index system generally follows the basic principles of operation, the combination of qualitative and quantitative methods, and the selection of indicators is as moderate as possible to avoid the distraction of the evaluators caused by the excessive size of the system or the one-sided evaluation caused by the too small system. The evaluation of network maturity includes two aspects: quality and quantity, the qualitative aspect mainly includes the network scale, such as the behavior subject network connection scale, the behavior personal network connection scale, and the quantity includes a little more aspects. For example, the ability of network self-renewal, the openness of the network, the stability, diversity and strength of network connections, and so on ${ }^{[8]}$.

The maturity level of collaborative innovation network in the park is divided into four levels, namely, low level, intermediate level, good level and excellent level, which is expressed by $\mathrm{N}, \mathrm{N}=\{\mathrm{N} 1, \mathrm{~N} 2, \mathrm{~N} 3, \mathrm{~N} 4\}$. 
Table 2. Formatting sections, subsections and subsubsections.

\begin{tabular}{ccccc}
\hline Grade & low level & intermediate level & good level & excellent level \\
\hline Range & $0 \sim 0.2$ & $0.2 \sim 0.5$ & $0.5 \sim 0.6$ & $0.6 \sim 1$ \\
\hline
\end{tabular}

Table 3. Comprehensive correlation degree and Evaluation results of Collaborative Innovation Network maturity.

\begin{tabular}{|c|c|c|c|c|c|c|}
\hline Park name & N1 & N2 & N3 & N4 & $\begin{array}{l}\text { Maximum } \\
\text { membership } \\
\text { principle }\end{array}$ & Grade \\
\hline Tongzhou & -0.8494 & -0.9403 & -0.8145 & -0.8928 & -0.8145 & good \\
\hline Yanqing & -0.7196 & -0.7430 & -0.7758 & -0.6400 & -0.6400 & excellent \\
\hline Anqing & -0.7591 & -0.8450 & -0.6915 & -0.8283 & -0.6915 & good \\
\hline Bengbu & -0.7358 & -0.8137 & -0.6492 & -0.8104 & -0.6492 & good \\
\hline Changping & -0.7016 & -0.7689 & -0.6716 & -0.6777 & -0.6716 & good \\
\hline Chizhou & -0.7529 & -0.8094 & -0.7666 & -0.787 & -0.7529 & low \\
\hline Fangshan & -0.7722 & -0.8088 & -0.6746 & -0.7649 & -0.6746 & good \\
\hline Hefei & -0.7460 & -0.8190 & -0.7194 & -0.5642 & -0.5642 & excellent \\
\hline Huaibei & -0.7747 & -0.8439 & -0.7358 & -0.8404 & -0.7358 & good \\
\hline Jinzhou & -0.8021 & -0.8657 & -0.7792 & -0.8225 & -0.7792 & good \\
\hline Lvshun & -0.7497 & -0.8326 & -0.6498 & -0.8096 & -0.6498 & good \\
\hline Miyun & -0.7823 & -0.8769 & -0.9674 & -0.8951 & -0.7823 & low \\
\hline Pinggu & -0.8273 & -0.9375 & -0.7897 & -0.9226 & -0.7897 & good \\
\hline Shunyi & -0.7813 & -0.8595 & -0.7578 & -0.8689 & -0.7578 & good \\
\hline Suzhou & -0.7224 & -0.7974 & -0.7219 & -0.8146 & -0.7219 & good \\
\hline
\end{tabular}

Table 4. Asymmetric closeness and Evaluation results of Collaborative Innovation Network maturity.

\begin{tabular}{|c|c|c|c|c|c|c|}
\hline Park name & B1 & B2 & B3 & B4 & $\begin{array}{c}\text { Approaching } \\
\text { principle }\end{array}$ & Grade \\
\hline Tongzhou & -0.1813 & -0.192 & -0.1768 & -0.1838 & -0.1768 & good \\
\hline Yanqing & -0.0987 & -0.1011 & -0.1051 & -0.0869 & -0.0869 & excellent \\
\hline Anqing & -0.1292 & -0.1386 & -0.1208 & -0.1347 & -0.1208 & good \\
\hline Bengbu & -0.1131 & -0.1216 & -0.1024 & -0.1190 & -0.1024 & excellent \\
\hline Changping & -0.0904 & -0.0974 & -0.0855 & -0.0821 & -0.0821 & excellent \\
\hline Chizhou & -0.1274 & -0.1335 & -0.1302 & -0.1315 & -0.1274 & low \\
\hline Fangshan & -0.1209 & -0.1249 & -0.1065 & -0.1138 & -0.1065 & good \\
\hline Hefei & -0.1034 & -0.1113 & -0.095 & -0.0693 & -0.0693 & excellent \\
\hline Huaibei & -0.1384 & -0.1461 & -0.1341 & -0.1453 & -0.1341 & good \\
\hline Jinzhou & -0.1513 & -0.1585 & -0.1482 & -0.1512 & -0.1482 & good \\
\hline Lvshun & -0.1192 & -0.1283 & -0.1062 & -0.1217 & -0.1062 & good \\
\hline Miyun & -0.1701 & -0.1808 & -0.202 & -0.1941 & -0.1701 & low \\
\hline Pinggu & -0.1750 & -0.1879 & -0.1713 & -0.1859 & -0.1713 & good \\
\hline Shunyi & -0.1464 & -0.1552 & -0.1448 & -0.1576 & -0.1448 & good \\
\hline Suzhou & -0.1156 & -0.1236 & -0.1177 & -0.1284 & -0.1156 & low \\
\hline
\end{tabular}

\section{Improved matter-element extension model}

Matter-element extension model uses matter-element model and extension set to transform practical problems in system research into formal problem models, and to transform incompatible problems into compatible problems. The basic steps are to determine the matter element, classical domain and section domain of each evaluation index, to determine the correlation function and correlation degree, and to input the measured value of the quantized index into the operation model to calculate the weight of each evaluation index, then bring the closeness function to obtain the closeness value under each grade.

The traditional matter-element model generally uses the simple and practical principle of maximum membership degree to determine the level. However, considering the effectiveness of the maximum membership principle, this paper uses the asymmetric closeness method to obtain the comprehensive correlation degree, and then selects the proximity principle to determine the grade of the evaluation object, so as to avoid the inefficiency or even ineffectiveness of the maximum membership principle ${ }^{[9]}$. Moreover, in order to make the calculated weight more reasonable, the analytic hierarchy process and entropy weight method each accounting for $50 \%$ are selected to obtain the comprehensive weight of each index.

\section{Empirical research}

The data come from the monitoring data of the park in 18 and 19. Some parks with missing statistical data were 
excluded, and 257 parks were selected as the research object. Partial results of comprehensive correlation degree and asymmetric proximity degree of the maturity of collaborative innovation network in the park are shown in Table 3 and Table 4 respectively. According to the principle of maximum membership, among the 257 National Agro-technology Parks, 55 parks such as Chizhou National Agro-technology Park in Anhui Province and Miyun National Agro-technology Park in Beijing Province are at a low level; 178 parka such as Anhui Anqing National Agro-technology Park and Anhui Bengbu National Agro-technology Park are in good grades; 24 parks such as Hefei National Agrotechnology Park in Anhui, Yanqing National Agrotechnology Park in Beijing are in excellent grade.

According to the principle of asymmetric closeness, among the 257 National Agro-technology Parks, 67 are at the low level, such as Chizhou National Agrotechnology Park, Miyun National Agro-technology Park and Suzhou National Agro-technology Park. 159 parks such as Anhui Anqing National Agro-technology Park, Beijing Pinggu National Agro-technology Park and Anhui Huaibei National Agro-technology Park are in good grade. 31 parks, such as Anhui Bengbu National Agro-technology Park, Anhui Hefei National Agrotechnology Park, Beijing Changping National Agrotechnology Park and Beijing Yanqing National Agrotechnology Park, are in excellent grade.

\section{Conclusion}

(1) The comprehensive weight is obtained by analytic hierarchy process (AHP) and entropy weight method ( $50 \%$ each), which can reduce the error caused by subjective deviation.

Through the improved matter-element extension model and introducing the asymmetric closeness degree to distinguish the grade of the park and increase the effectiveness of the grade result, this paper provides a new theoretical method for judging the maturity level of the collaborative innovation network of the National Agro-technology Park.

(2) Referring to the annual reports and monitoring reports of the park in recent years, the improved matterelement extension model is used to measure the maturity level of collaborative innovation network in park. The results show that compared with the maximum membership principle, the results obtained by asymmetric closeness method are more in line with the actual situation.

(3) The final results show that among the 257 National Agro-technology Parks, 67 parks are in the low level, 159 parks are in the good level, 31 parks are in the excellent level, and no park is in the intermediate level. Overall, the National Agro-technology Park collaborative innovation network maturity quality is good, and about $25 \%$ of the park maturity level is low can not be ignored. If the classification standard changes, the level of the park may change accordingly.

(4) The intensive development of green innovation in National Agro-technology Parks is inseparable from multi-party participation. In addition to the active guidance of government policies and the participation of social forces, the park itself should also increase its investment in innovation. Meanwhile, through innovation-driven development instead of the traditional resource input-driven development model, the park will achieve low energy consumption, intensive and highquality development, and promote innovative projects with both ecological and economic benefits to "take root" and "blossom and bear fruit".

\section{Acknowledgement}

Fund project: Humanities and Social Sciences Project of the Ministry of Education: Study on the interaction between Comprehensive performance of Agricultural Science and Technology Park and County Innovation Development under Innovation-driven Development Strategy (18YJC630056); Key projects of Scientific Research Program of Colleges and Universities in Shandong Province: Study on the interaction between the Comprehensive performance of Agricultural Science and Technology Parks in Shandong Province and the Development of County economy under the Innovationdriven Strategy (J18RZ004); Special Project of Social Science Planning in Shandong Province: Research on Information Poverty Alleviation in the implementation of Rural Revitalization Strategy (18CHLJ45)

\section{References}

1. Qing L. Northeast Forestry University. Study on the Demonstration Driving Ability of Regional Agricultural Science and Technology Park. (2006)

2. Xinan C. Today's Technology, 5, 3-4. (2018).

3. Kejie L. Jinan University. Research on Regional Innovation Network of Industrial Cluster. (2006)

4. Wenhua J., Zhitai Z. Journal of Langfang Normal University (NATURAL SCIENCE EDITION), 14, 76-80. (2014)

5. Zongyu H. Research on Collaborative Innovation Network and Innovation Performance of Science and Technology Park Innovation Community. (2015)

6. Hanwen L. Research on Evolution Mechanism of Collaborative Innovation Network in Science and Technology Park. (2015)

7. Sen L., Li Z. Science and Technology Information, 15, 238-240. (2017)

8. Yaqiong H., Pei Q.Journal of Harbin Institute of Technology (SOCIAL SCIENCE EDITION), 06, 88-92. (2005)

9. Xiaoping Z.Journal of Shandong University (SCIENCE EDITION), 02, 25-29. (2004) 